\title{
Practice-based learning: Medico-legal evidence collection as part of post-rape care in refugee contexts
}

Michael Gaitho

Ronald Kotut

Anne Ngunjiri

Jane T. Thiomi

Josephine Ngebeh

See next page for additional authors

Follow this and additional works at: https://knowledgecommons.popcouncil.org/departments_sbsr-rh

Part of the Demography, Population, and Ecology Commons, International Public Health Commons, Medicine and Health Commons, and the Migration Studies Commons

How does access to this work benefit you? Let us know!

\section{Recommended Citation}

Gaitho, Michael, Ronald Kotut, Anne Ngunjiri, Jane T. Thiomi, Josephine Ngebeh, and Chi-Chi Undie. 2020. "Practice-based learning: Medico-legal evidence collection as part of post-rape care in refugee contexts," Sauti/VOICE Program Brief Series, no. 6. Nairobi: UNHCR EHAGL Africa Bureau, LVCT Health, and Population Council. 
Authors

Michael Gaitho, Ronald Kotut, Anne Ngunjiri, Jane T. Thiomi, Josephine Ngebeh, and Chi-Chi Undie 


\section{Practice-Based Learning: Medico-Legal Evidence Collection as Part of Post-Rape Care in Refugee Contexts}

Health care providers collect an array of documentation and specimens to support criminal investigations. Such documentation and specimens are referred to as 'medico-legal' or 'forensic' evidence, and in the case of rape, include a survivor's documented injuries and emotional state at the time of examination, as well as samples and specimens from the survivor's body or clothing (e.g. saliva, seminal fluid, head or pubic hair, blood, urine, fibers, debris).

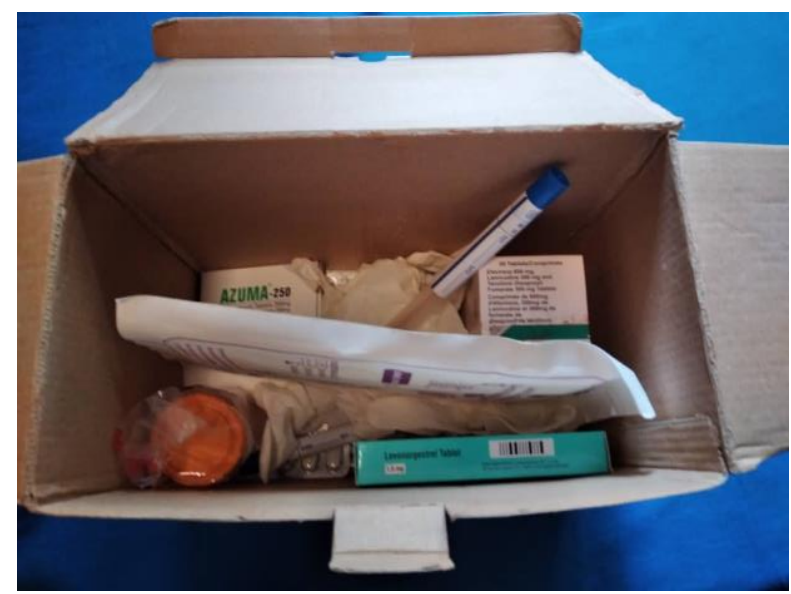

Figure 1: Locally-assembled sexual assault kit. Credit: UNHCR Tanzania
For survivors of rape and defilement who want to obtain legal justice, medico-legal evidence is critical. In African countries, health providers and the police are depended upon to ensure such evidence is collected, but medico-legal evidence collection can present challenges. Evidence-based interventions are needed to improve the efficacy of medico-legal and forensic evidence collection.

In collaboration with the Population Council-led Africa Regional SGBV Network, UNHCR's East, Horn of Africa and Great Lakes (EHAGL) Regional Bureau has been facilitating the integration of a tested intervention to improve medico-legal evidence collection within its operational programming. This brief provides notable lessons from these efforts.

\section{Intervention Description}

Pioneered in Kenya by Africa Regional SGBV Network partner LVCT Health, this innovative intervention uses a dual approach to facilitate collection of medico-legal evidence. First, sexual assault kits are assembled from items (listed in Table 1) typically already available in health facilities. These locally-assembled kits of various materials post-rape care providers need to attend to survivors, are stored in one designated room for post-rape care response in health facilities. These kits help simplify the response to refugee survivors, reducing their movement from one area of service delivery to another, and easing health providers' processes of tracking health services received by refugee survivors.

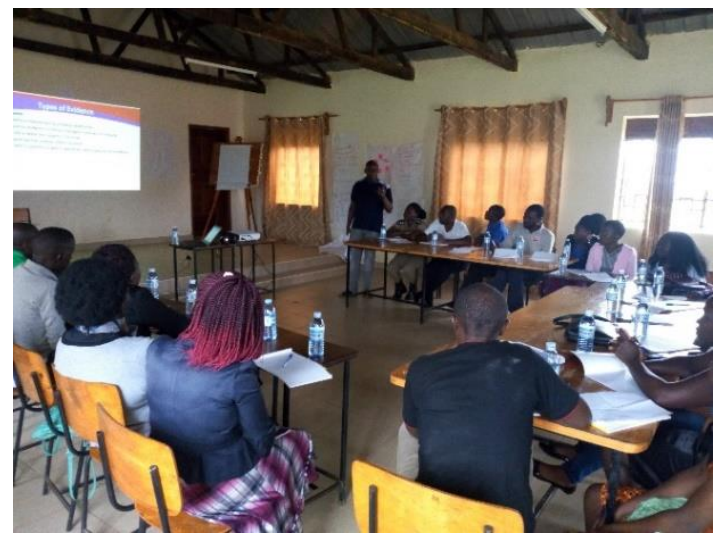

Figure 2: Training in Nakivale, Uganda. Credit: LVCT Health
SN UNCR The UN Refugee Agency

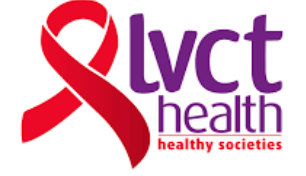

POPULATION COUNCIL

Ideas. Evidence. Impact. 
The intervention then ensures that each country's medico-legal documentation forms (often admissible in courts of law) are properly understood by responsible parties, to ensure their proper interpretation and completion. This aspect of the intervention engages post-rape care health, police, and legal service providers in conversations with one another at a three day multi-sectoral training, focusing on: 1) reviewing the country's post-rape care form (completed by care providers at health facilities) and police form (filled out by police at police stations), 2) fostering understanding of each sector's role in proper form completion, and of how proper completion of these forms enhances legal outcomes for refugee survivors, and 3) resolving

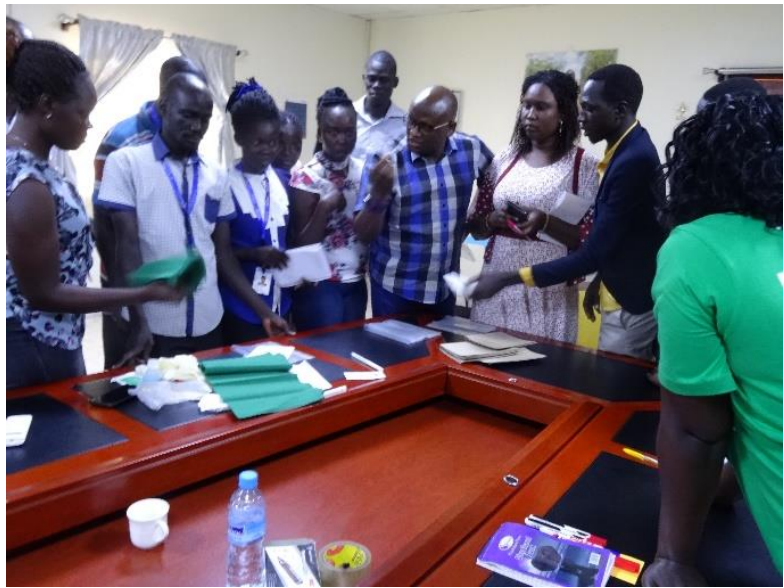

Figure 3: Training in Maban, South Sudan. Credit: LVCT Health referral pathway concerns and other issues that hinder proper and complete medico-legal evidence collection and limit survivors' chances for justice.

\section{Participating Countries}

UNHCR's EHAGL Africa Bureau covers 11 countries in the East, Horn, and Great Lakes Region of Africa. Three of these countries-South Sudan, Tanzania, and Uganda-are receiving technical support from LVCT Health, and by October 2019 , had been trained to facilitate the implementation of this intervention in seven refugee camps and settlements.

\section{Lessons}

\section{Feasibility of assembling sexual assault kits locally in refugee settings}

The components of a sexual assault kit are outlined in Table 1 , which illustrates that assembling sexual assault kits is feasible in refugee settings, as many components are consistently available at health facilities; in this intervention's participating countries, about half of the required components are readily available in refugee camp health facilities. Only three components require a one-time purchase, with the rest requiring routine procurement to ensure service continuity.

While sexual assault kits were not in use in any refugee camps or settlements before this initiative, kits were

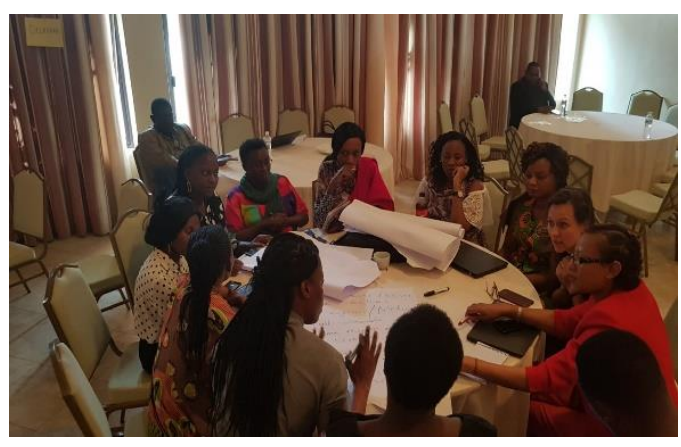

Figure 4: Training in Kigoma, Tanzania. Credit: LVCT Health available in certain capital cities (such as the Juba Teaching Hospital's Family Protection Center, a onestop center for SGBV care in Juba, South Sudan), and were thereby available to refugee survivors accessing care in such cities and hospitals. 


\section{Standardizing medico-legal evidence documentation processes in refugee settings}

Processes for documenting medico-legal evidence vary by country. In some contexts, police forms are available only at police posts or stations, and can only be completed by a single designated doctor. In other refugee settings, any qualified doctor is permitted to complete police forms for sexual violence cases. In some settings, there is strong collaboration between health facilities and police stations in completing police forms, particularly where those sites are proximate. At some participating sites, police officers accompany survivors to health facilities (when survivors use police stations as their entry point for seeking services), then ensure the police form is completed by the clinician, and return the completed form to the police station for further legal action.

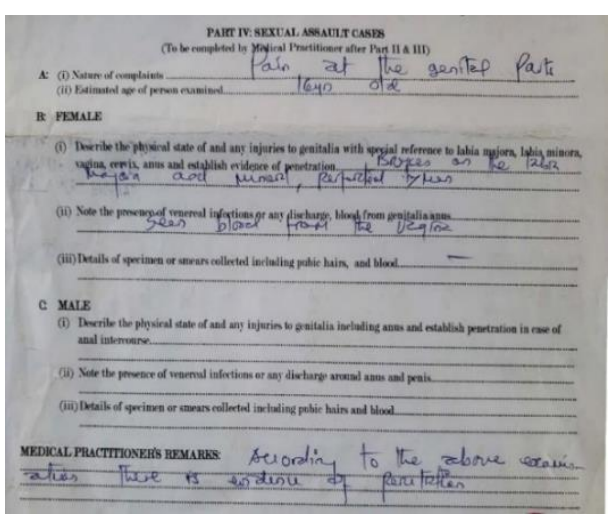

Figure 5: Filled out police form Credit: UNHCR Tanzania

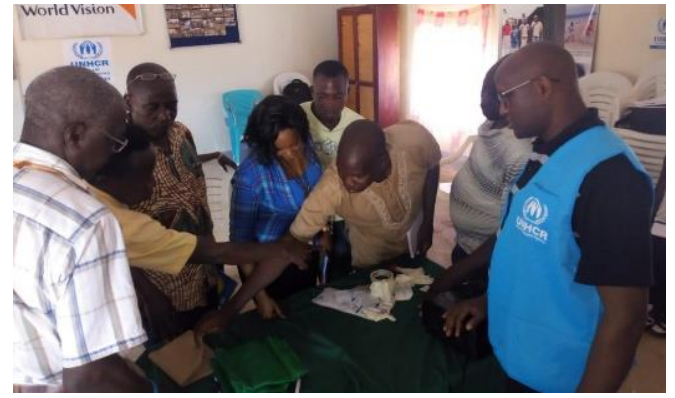

Figure 6: Training in Yambio, South Sudan. Credit: UNHCR South Sudan
Conversely, certain contexts present barriers to survivors' timely access to post-rape care, ranging from inconsistent availability of police forms, to requirements for survivors' presentation at health facilities with a police form to be eligible for post-rape care, to the onus of transferring police forms between health facilities and police stations being placed on survivors themselves. These variances in procedures indicate the need to standardize medico-legal evidence documentation and related issues, incorporating what is working well and eliminating what is not.

\section{Forensic evidence training needs in refugee settings}

Post-rape care providers in health facilities are aware of their responsibility to collect samples from survivors as medico-legal evidence for use in court, but all such providers in participating sites require formal training in forensic evidence collection to facilitate the proper utilization of sexual assault kits to serve survivors.

\section{Forensic evidence storage needs in refugee settings}

While DNA testing is, understandably, unavailable in participating refugee camps and settlements, simple tests such as vaginal swabs are feasible to conduct and adequate for forensic purposes. To maximize forensic evidence in these settings, necessary storage facilities for evidence (e.g. lockable cabinets, specimen freezers) in health facilities and police stations must be prioritized. These facilities are largely lacking at participating sites. Furthermore, the referral pathway between the Government Chemist and both health facilities and police stations needs to be clarified and publicized to all duty-bearers. 
Table 1: Contents of a Sexual Assault/Post-Rape Care Kit

\begin{tabular}{|c|c|c|c|c|}
\hline \multirow[t]{2}{*}{ ITEM } & \multirow[t]{2}{*}{ PURPOSE } & \multicolumn{3}{|c|}{ AVAILABILITY IN PARTICIPATING SITES } \\
\hline & & $\begin{array}{c}\text { Available } \\
\text { in health care } \\
\text { facilities }\end{array}$ & $\begin{array}{l}\text { Routine } \\
\text { procurement } \\
\text { required }\end{array}$ & $\begin{array}{l}\text { One-time } \\
\text { purchase } \\
\text { required }\end{array}$ \\
\hline Powder-free gloves & To avoid contamination & $\checkmark$ & & \\
\hline Sterile gloves & $\begin{array}{l}\text { For sterile procedures } \\
\text { (such as collecting high vaginal swabs } \\
\text { (HVS)) }\end{array}$ & $\checkmark$ & & \\
\hline 6 stick swabs & $\begin{array}{l}\text { For taking HVS and/or anal swabs } \\
\text { from survivor }\end{array}$ & $\checkmark$ & & \\
\hline Tape measure & $\begin{array}{l}\text { For measuring any physical injuries } \\
\text { found on survivor }\end{array}$ & & & $\checkmark$ \\
\hline Needles and syringes & \multirow{2}{*}{ For collection of blood samples } & $\checkmark$ & & \\
\hline Vercutainer tubes & & $\checkmark$ & & \\
\hline Urine bottles & For collection of urine samples & $\checkmark$ & & \\
\hline Speculum & $\begin{array}{l}\text { For collection of specimens } \\
\text { from vaginal cavity }\end{array}$ & $\checkmark$ & & \\
\hline Pregnancy testing kit & To test for pregnancy & $\checkmark$ & & \\
\hline Seal lock bags & $\begin{array}{l}\text { For proper storage of collected } \\
\text { specimens }\end{array}$ & & $\checkmark$ & \\
\hline Green towels & $\begin{array}{l}\text { For wiping hands during sterile } \\
\text { procedure, and placing beneath } \\
\text { survivor's buttocks }\end{array}$ & & $\checkmark$ & \\
\hline Comb & $\begin{array}{l}\text { Combing hair from various body parts } \\
\text { to obtain evidence }\end{array}$ & & & $\checkmark$ \\
\hline Nail cutter & For trimming fingernails & & & $\checkmark$ \\
\hline Brown envelopes & $\begin{array}{l}\text { For proper storage of collected } \\
\text { specimens }\end{array}$ & & $\checkmark$ & \\
\hline Masking tape & $\begin{array}{l}\text { For sealing the brown envelopes } \\
\text { in which specimens have been stored }\end{array}$ & & $\checkmark$ & \\
\hline $\begin{array}{l}\text { Labels } \\
\text { (muskin tape) }\end{array}$ & $\begin{array}{l}\text { For labeling brown envelopes with details } \\
\text { of specimens stored therein }\end{array}$ & & $\checkmark$ & \\
\hline $\begin{array}{l}\text { Cloth } \\
\text { (as part of dignity kit) }\end{array}$ & $\begin{array}{l}\text { For survivor to exchange with original } \\
\text { clothing }\end{array}$ & & $\checkmark$ & \\
\hline $\begin{array}{l}\text { Disposable underwear } \\
\text { (as part of dignity kit) }\end{array}$ & $\begin{array}{l}\text { For survivor to exchange with original } \\
\text { clothing }\end{array}$ & & $\checkmark$ & \\
\hline
\end{tabular}




\section{References}

Ajema C., Mukoma W., Kotut R., Mulwa R. (2015). Documenting medico-legal evidence in Kenya: Potential strategies for improvement. BMC Proceedings 9(Suppl 4): A2.

www.ncbi.nlm.nih.gov/pmc/articles/PMC4496633/.

Ajema C, Mukoma W, Mugyenyi C, Meme M, Kotut R, and Mulwa R (2012) Improving the collection, documentation and utilisation of medico-legal evidence in Kenya. Nairobi: LVCT Health.

Du Mont J, White, D. (2002). The uses and impacts of medico-legal evidence in sexual assault cases: A global review. Geneva: World Health Organization.

Since 2006, the Population Council-led Africa Regional SGBV Network has worked to build effective responses to SGBV in low-resource settings, focusing on those who have experienced violence, as well as on violence prevention. From 2018-2020, the network is collaborating with the UNHCR EHAGL Africa Bureau in Nairobi, Kenya, to address the needs of survivors in refugee settings in the East, Horn, and Great Lakes Regions of Africa through the ViOlence Response and Prevention through Information, Communication, and Education (VOICE) project. 'Voice' is translated as 'Sauti' in Kiswahili, and represents the project's emphasis on amplifying the voices of SGBV survivors and the efforts of those that work with them (UNHCR implementing partners and the network's civil society organizations), to broaden the reach of effective SGBV responses across the region.

(C2020 UNHCR EHAGL Africa Bureau and the Population Council, Inc.

Citation: Michael Gaitho, Ronald Kotut, Anne Ngunjiri, Jane T. Thiomi, Josephine Ngebeh, Chi-Chi Undie. 2020. 'Practice-Based Learning: Medico-Legal Evidence Collection as Part of Post-Rape Care in Refugee Contexts.' The Sauti/VOICE Program Brief Series, Brief 6. Nairobi, Kenya: UNHCR EHAGL Africa Bureau, LVCT Health, and Population Council.

\author{
UNHCR EHAGL Africa Bureau \\ Contact: \\ Josephine Ngebeh \\ UNHCR EHAGL Africa Bureau \\ APHRC Campus, Kitisuru \\ P. O. Box 43801-00100 \\ Nairobi, Kenya \\ ngebeh@unhcr.org
}

\author{
LVCT Health Contact: \\ Michael Gaitho \\ LVCT Health \\ Argwings Kodhek Road \\ P. O. Box 19835-00202 \\ Nairobi, Kenya \\ Michael.gaitho@lvcthealth.org \\ www.Ivcthealth.org
}

\author{
Africa Regional SGBV \\ Network Contact: \\ Chi-Chi Undie \\ Population Council \\ Avenue 5, Rose Avenue \\ Hurlingham \\ P. O. Box $17643-00500$ \\ Nairobi, Kenya \\ cundie@popcouncil.org
}

